\title{
Группа органов банковского надзора по оффшорам как механизм международно- правового регулирования деятельности оффшорных финансовых центров
}

Асланов А.X.*

В статье рассматриваются условия членства и участия в Группе органов банковского надзора по оффшорам (ОГБС), её деятельность и задачи, а также сотрудничество в работе международных инициатив в области правового регулирования деятельности финансовых оффшорных центров.

Ключевые слова: финансовый оффшорный центр; «отмывание» денег; легализация доходов, полученных преступным путем; коррупция.

Группа органов банковского надзора по оффшорам (The Offshore Group of Banking Supervisors, далее ОГБС) была создана в 1980 году по инициативе Базельского Комитета по банковскому надзору как объединение компетентных органов банковского надзора, представляющих оффшорные финансовые центры.

Основными условиями членства в ОГБС являются ${ }^{1}$ :

- строгое принятие обязательств придерживаться принципов эффективного банковского надзора, отраженных в Конкордате Базельского Комитета 1983 года, приложении к Конкордату, Минимальных стандартах по надзору за международными банковскими группами и их трансграничными международных учреждениями 1992 года и в Основных Принципах эффективного банковского надзора, принятых Базельским комитетом по банковскому надзору в 1997 году;

- строгое принятие обязательств придерживаться в своей деятельности Сорока рекомендаций ФАТФ и девяти специальных рекомендаций ФАТФ по борьбе с финансированием терроризма;

\footnotetext{
* Асланов Анвар Халимович - магистр международного права, соискатель Университета мировой экономики и дипломатии при Министерстве Иностранных дел Республики Узбекистан; начальник юридического департамента Узбекско-Корейского Банка «УзКДБ Банк». anvar.aslanov@gmail.com.

${ }^{1}$ Официальный сайт Группы органов банковского надзора по оффшорам [электронный peсурс]. Режим доступа: www.ogbs.net.
} 
- необходимые правовые и административные ресурсы, позволяющие осуществить эти обязательства.

Членами ОГБС являются: Аруба, Багамские острова, Бахрейн, Барбадос, Бермудские острова, Каймановы острова, Кипр, Гибралтар, остров Гернси, Мэн, Джерси, Лабуан, Макао, Китай, Маврикий, Антильские острова, Панама, Сингапур и Вануатуㄹ․ Статусом наблюдателя обладают Британские Виргинские острова, Восточно-Карибский Центральный Банк и Самоа.

Группа органов банковского надзора по оффшорам участвует в работе ФАТФ в качестве организации со статусом наблюдателя. ОГБС имеет равный правовой статус с региональными организациями, созданными по типу ФАТФ (Азиатско-Тихоокеанская группа по борьбе с «отмыванием» денег (APG), Специальная группа по финансовым мероприятиям стран Карибского бассейна (CFATF), Восточно- и Южно-Африканская группа по борьбе с «отмыванием» денег (ESAAMLG) и т.д.). ОГБС принимает участие в деятельности рабочих групп, создаваемых ФАТФ, в частности, при активном участии ОГБС была выработана Методология оценки соблюдения Сорока рекомендаций ФАТФ, а также девяти специальных рекомендаций по борьбе с финансированием терроризма.

ОГБС в 1997г. было достигнуто соглашение с ФАТФ о процедуре оценки имплементации членами ОГБС мер, направленных на борьбу с легализацией доходов, полученных преступным путем. Бахрейн, Гонконг и Сингапур участвуют в программе взаимной оценки, проводимой ФАТФ; Кипр участвует в программе взаимной оценки, проводимой Советом Европы совместно с ОГБС; семь государств - членов ОГБС (Аруба, Багамские острова, Барбадос, Бермудские острова, Каймановы острова, Нидерландские Антильские острова и Панама) являются участниками программы взаимной оценки, осуществляемой Специальной группой по финансовым мероприятиям стран Карибского бассейна (CFATF). Уровень правового регулирования и соответствия международным стандартам в Гибралтаре, Гернси, на острове Мэн, Джерси и Маврикии подлежит оценке в соответствии с определенной процедурой, согласованной между ОГБС и ФАТФ. Азиатско-Тихоокеанская группа по борьбе с «отмыванием» денег (APG) совместно с ОГБС оце-

2 Вахания В. В. Международные финансовые институты и контрольные механизмы. М.: «Финансы и кредит», 2004, с.. 339. 
нивает уровень соответствия международным стандартам в Лабуане, Макао и Вануатуㄹ.

В качестве задач на перспективу ОГБС выделяет:

- участие в дальнейшем в процессе взаимной оценки соблюдения международных стандартов в области борьбы с легализацией доходов, полученных преступным путем, разработанной ФАТФ;

- продолжение активного участия в процессе пересмотра Сорока рекомендаций ФАТФ;

- продолжение оказания активного содействия соблюдению Сорока рекомендаций ФАТФ и Девяти специальных рекомендаций по борьбе с финансированием терроризма;

- поддержку программы оценки финансового регулирования и мер, направленных на борьбу с легализацией доходов, полученных преступным путем, осуществляемой Международным валютным фондом;

- поощрение повышения финансовыми оффшорными центрами стандартов в своей деятельности для того, чтобы они отвечали условиям членства в ОГБС;

- поощрение участия государств и территорий, являющихся членами ОГБС, в программах, направленных на улучшение финансового регулирования и мер, направленных на борьбу с легализацией доходов, полученных преступным путем, которые осуществляются Институтом финансовой стабильности Банка международных расчетов, а также другими международными, региональными и национальными организациями;

- продолжение участия в работе совместной рабочей группы Базельского комитета;

- продолжение оказания активного содействия соблюдению Основных принципов эффективного банковского надзора, принятых Базельским комитетом;

- оказание активной поддержки развитию международных стандартов в борьбе с коррупцией, включая участие во встречах Комитета Ad Нос на переговорах по принятию Конвенции ООН против коррупции;

- продолжение сотрудничества со всеми компетентными организациями в разработке международных стандартов в сфере финансо-

\footnotetext{
${ }^{3}$ Официальный сайт Группы органов банковского надзора по оффшорам [электронный pecypc]. Режим доступа: www.ogbs.net.
} 
вого регулирования и борьбы с легализацией доходов, полученных преступным путем, а также в процессе оценки их соблюдения 4 .

Исходя из вышеизложенного следует, что ОГБС является одним из важных механизмов складывающегося международно-правового регулирования деятельности оффшорных финансовых центров, в частности, благодаря своей специализации на регулировании банковской деятельности, которая играет ключевую роль в деятельности многих оффшорных финансовых центров.

\section{Библиографический список}

Вахания В. В. Международные финансовые институты и контрольные механизмы. М.: «Финансы и кредит», 2004, с. 339.

Официальный сайт Группы органов банковского надзора по оффшорам [электронный ресурс]. Режим доступа: www.ogbs.net.

\section{The Offshore Group of Banking Supervisors as a Mechanism of International Legal Regulation of Financial Offshore Centers (Summary)}

Anvar Kh. Aslanov*

This article discusses the conditions of membership and participation in The Offshore Group of Banking Supervisors (OGBS), its activities and objectives, as well as cooperation in international initiatives in the area of legal regulation of offshore financial centers.

Keywords: offshore financial center; money laundering; legalization of incomes derived from criminal activities; corruption.

\footnotetext{
${ }^{4}$ Официальный сайт Группы органов банковского надзора по оффшорам [электронный peсурс]. Режим доступа: www.ogbs.net.

* Anvar Kh. Aslanov - Master in International Law, post-graduate student of the University of World Economy and Diplomacy under the Ministry of Foreign Affairs of Uzbekistan; head of Legal Department, Uzbekistan Korean Development Bank (UzKDB Bank). anvar. aslanov@gmail.com.
} 